\title{
Adoption Constraints of Improved Techniques for Kitchen Gardening in Chittorgarh District of Rajasthan, India
}

\author{
Deepa Indoria $^{1 *}$, C.M. Balai, Bharti ${ }^{2}$ and R.L. Solanki \\ ${ }^{1}$ Krishi Vigyan Kendra (MPUAT), Dungarpur - 314 001, Rajasthan, India \\ ${ }^{2}$ KVK, Dhanbad, Ranchi, Jharkhand, India \\ *Corresponding author
}

\section{A B S T R A C T}

Kitchen gardening plays an imperative role for rural families to recover diversified vegetables in their daily diet. Demonstrations on kitchen gardening have distorted the eye site of the tribal farm women among health and hygienic safety measures. The KVK

Keywords

Kitchen

Gardening,

Adoption,

FLDs,

IPM,

Innovation

Article Info

Accepted:

25 April 2017

Available Online:

10 May 2017
Chittorgarh demonstrated the kitchen gardening in tribal area. Since last three years about 100 FLDs on kitchen gardening was undertaken. To know the impact of the alleged technology along with constraints faced by tribal farm women the attempt were made. The results seen the overall knowledge of kitchen gardening indicated that the low, medium and high level of knowledge before contact with KVK was 85.00 per cent, 11.00 per cent and 4.00 per cent, respectively. It was altered up to 07.00 per cent, 13.00 per cent and 80.00 per cent after contact with KVK. In case of Knowledge regarding selected scientific innovations regarding kitchen gardening high knowledge regarding selected scientific innovations were found except IPM. Further majority of the tribal farm women had low level of knowledge (78.00 per cent) before contact with KVK. After contact with KVK, 88.00 per cent of the tribal farm women had high level of knowledge. At the end we can suggest these FLDs in the region found an important for increasing the income, improving the soil health, fertility and productivity and also to raise the standard of living of the tribes. However, some constraints were also faced by tribal farm women in adoption of kitchen gardening in scientific way. The input constraints were the most important constraints and were ranked in first position which needs to be solved for betterment of the tribes in the region.

\section{Introduction}

The tribal farm women cannot have enough wealth to purchase costly vegetables for their family. The sickle cell anemia and other diseases are great constraints in the region. The main reason behind this is malnutrition, imbalanced ration and illiteracy. Krishi Vigyan Kendra is a pioneering knowledge based institution which is engaged with transfer of scientific technology related to agriculture and allied fields in adopted villages of Chittorgarh district. In Chittorgarh district some tribal dominated villages with poor economic condition of farmers. The farm women of this area are mostly engaged with daily wages farm work which is available in particular crop season. Majority of tribal farm women have lack of knowledge about health and nutrition, dietetic blueprint of pregnant and lactating women and complementary feeding for children. Due to poor economic 
condition, they are unable to purchase fruits and vegetables from market for their daily dietary need. This is resulted in poor health and imbalance nutritional status of farmers, farm women and children. The farm women of this area are growing one or two vegetable crops of local variety in their backyard in traditional way. To motivate the farmwomen towards growing improved varieties of different vegetables to accomplish their nutritional requirement, to improve the health and nutritional status of tribal farm families, to increase the income of tribal farmers, to demonstrate kitchen gardening scientific way, to make farm women familiar with different vegetables and high value dietary vegetable crops. It has been decided to conduct front line demonstrations on kitchen gardening in adopted villages of Chittorgarh district. In spite of the importance of all facts still kitchen gardening is not a very successful venture in most of the families. The predominant reasons for the poor adoption may due to lack of technical guidance, lack awareness and knowledge factors such as seed, water, plant protection measures, storage, processing and so on. Considering the significance of constraints and impact the study was undertaken with following objectives; To know the overall knowledge of scientific package of practices of kitchen gardening. To study the knowledge regarding selected scientific innovations for kitchen gardening. To study the overall adoption of scientific package of practices of kitchen gardening. And also to find out the adoption of critical kitchen gardening and constraints faced by them in adoption of the technology.

\section{Materials and Methods}

The present study was conducted in district Chittorgarh of Rajasthan state. Four Panchayat samitee were selected, total 100 demonstrations were conducted on kitchen gardening in 5 villages of each four Panchayat Samities Gangrar (Amarpura, Lambia,
Ghaniya, Sudri, Mandpia), Chittorgarh (Nagri, satpura, Aawalhera, Surjansa, Aanchora) Bhadesar (Ghorakhera, Surajpura, Gopalpura, Sukhwara, Napaniya) and kapasan (Shanni maharaj, Kashya, Singhpur, Kasarkheri, Gora ji ka Nibhera) of district Chittorgarh. Among each village, 5 tribal farm women were selected randomly purposively for the study. Hence, total sample size was 100 tribal women. The data were collected through personal interview. The interview schedules were prepared by keeping the objectives of the study in mind. The necessary care was taken to collect the un biased and correct data. The data were collected, tabulated and analyzed to find out the findings and drawing the conclusion. The statistical tools like frequency, percentage and rank were employed to analyze the data. The constraints as perceived by respondents were scored on the basis of magnitude of the problem as per Meena and Sisodiya (2004). The respondents were recorded and converted into mean per cent score and constraints were ranked accordingly as per Warde et al., (1991).

\section{Results and Discussion}

It was tried to find out the level of knowledge of tribal farmwomen about package of practices of kitchen gardening. Knowledge as a body of understood information processed by an individual is one of the important components of behavior and plays an important role in adoption of an innovation. Keeping this view in mind, the level of knowledge of tribal farm women about package of practices of kitchen gardening was assessed. The data presented in the table 1 show that respondents were categorized into (i) low level of knowledge (ii) medium level of knowledge and (iii) high level of knowledge. The data in table 1 reveal that out of 100 respondents had 85.00 per cent low level, 11.00 per cent medium level and 4.00 per cent high level of knowledge about 
package of practices of kitchen gardening before contact with KVK. Whereas, 7.00, 13.00 and 80.00 per cent kept low, medium and high level of knowledge category about package of practices after contact with KVK. There results were in conformity with the results obtained by Javat et al., (2011) and Singh et al., (2010).

Knowledge of the respondents about improved technologies for kitchen gardening was assessed under five technologies viz., new high yielding varieties, integrated pest management, use of biofertilizers, weeding and integrated nutrient management. Perusal of table 2 depicts that farm women possessed good knowledge about improved technologies. Distribution of the farmers in various knowledge categories highlight that in new high yielding varieties, respondents belong to high knowledge category. Similarly majority of the respondents belong to high knowledge category in the improved technologies of integrated pest management (75), use of biofertilizers (71), weeding (69) and integrated nutrient management (78).

The extent of adoption of improved technologies for kitchen gardening by respondents was judged under three categories as low, medium and high level adoption on the basis on MPS. Perusal of the data in the table 3 that majority of farm women had low level of adoption of improved technologies before contact with KVK and only 10 respondents had high level of adoption whereas, after contact with KVK, 88 respondents had high level of adoption of improved technologies and only 5 respondents had medium level of adoption.

Table.1 Overall knowledge of package of practices of Kitchen gardening n=100

\begin{tabular}{|l|l|l|c|}
\hline S. No. & \multicolumn{1}{|c|}{ Category } & $\begin{array}{l}\text { Before contact with KVK } \\
(\boldsymbol{\%})\end{array}$ & After contact with KVK (\%) \\
\hline 1. & Low level of knowledge & 85.00 & 07.00 \\
\hline 2. & $\begin{array}{l}\text { Medium level of } \\
\text { knowledge }\end{array}$ & 11.00 & 13.00 \\
\hline 3. & High level of knowledge & 04.00 & 80.00 \\
\hline
\end{tabular}

Table.2 Distribution of farmers by their knowledge regarding improved technologies for Kitchen gardening

$\mathbf{n}=\mathbf{1 0 0}$

\begin{tabular}{|l|l|l|l|l|}
\hline S.No. & \multicolumn{1}{|c|}{ Selected scientific innovation } & \multicolumn{1}{c|}{ Low } & \multicolumn{1}{c|}{ Medium } & \multicolumn{1}{c|}{ High } \\
\hline 1 & New high yielding varieties & 09 & 6 & 85 \\
\hline 2 & Integrated Pest Management & 12 & 13 & 75 \\
\hline 3 & Bio fertilizer & 11 & 18 & 71 \\
\hline 4 & Weeding & 23 & 8 & 69 \\
\hline 5 & Integrated Nutrient management & 09 & 13 & 78 \\
\hline
\end{tabular}

Table.3 Overall adoption of scientific cultivation of Kitchen gardening

$\mathbf{n}=\mathbf{1 0 0}$

\begin{tabular}{|l|l|c|c|}
\hline S. No. & \multicolumn{1}{|c|}{ Category } & Before contact with KVK(\%) & After contact with KVK(\%) \\
\hline 1. & Low level of adoption & 78 & 07 \\
\hline 2. & Medium level of adoption & 12 & 05 \\
\hline 3. & High level of adoption & 10 & 88 \\
\hline
\end{tabular}


Table.4 Constraints in adoption of scientific cultivation of Kitchen gardening

\begin{tabular}{|c|c|c|c|}
\hline S. No. & Particulars & MPS & Rank \\
\hline A. & Input Constraints & & \\
\hline 1. & Unavailability of high yielding varieties of vegetable seeds & 81.26 & 1 \\
\hline 2. & Lack of irrigation facility due to scarcity of water in area & 75.50 & 2 \\
\hline 3. & Unavailability of land for kitchen gardening near residential zone & 73.14 & 3 \\
\hline 4. & Cow dung is utilized as fuel hence organics are less available & 64.81 & 4 \\
\hline \multirow[t]{2}{*}{5.} & Specific eco friendly insecticides are unavailable in market & 51.55 & 5 \\
\hline & Overall & 69.25 & \\
\hline B. & Technical Constraints & & \\
\hline 1. & $\begin{array}{l}\text { Lack of knowledge regarding sowing time, improved varieties and } \\
\text { seed rate }\end{array}$ & 82.00 & 1 \\
\hline 2. & $\begin{array}{l}\text { Lack of knowledge regarding nutritious fruits and vegetables } \\
\text { selection }\end{array}$ & 74.45 & 2 \\
\hline 3. & $\begin{array}{l}\text { Lack of knowledge regarding major pests. it's identification and } \\
\text { management }\end{array}$ & 65.64 & 3 \\
\hline 4. & Lack of knowledge regarding critical growth stages for irrigation & 54.75 & 4 \\
\hline 5. & $\begin{array}{l}\text { Lack of knowledge regarding manures and fertilizers } \\
\text { recommendation }\end{array}$ & 53.76 & 5 \\
\hline 6. & Lack of knowledge regarding seed multiplication & 52.12 & 6 \\
\hline \multirow[t]{2}{*}{7.} & Lack of knowledge regarding seed treatment & 47.35 & 7 \\
\hline & Overall & 61.43 & \\
\hline C. & Socio-cultural constraints & & \\
\hline 1. & Fear of farm produce robbery & 72.31 & 1 \\
\hline 2. & prejudices/ orthodoxy & 64.55 & 2 \\
\hline 3. & Age old traditional practices adoption & 60.76 & 3 \\
\hline 4. & Migration of Rural youth towards urban area & 55.26 & 4 \\
\hline \multirow[t]{2}{*}{5.} & Low involvement of housewife in cultivation practices & 51.23 & 5 \\
\hline & Overall & 60.82 & \\
\hline D. & General constraints & & \\
\hline 1. & High poultry and monkey menace & 71.86 & 1 \\
\hline 2. & Problem of proper protection of local goat and cattle grazing & 60.15 & 2 \\
\hline 3. & $\begin{array}{l}\text { Less priority of kitchen gardening as compared with other farm } \\
\text { activities }\end{array}$ & 52.19 & 3 \\
\hline \multirow[t]{2}{*}{4.} & Frequent deluge of kitchen garden during rainy season & 40.78 & 4 \\
\hline & Overall & 56.24 & \\
\hline
\end{tabular}

Table.5 Major constraints faced by farm women in adoption of Kitchen gardening

\begin{tabular}{|l|l|c|c|}
\hline S. No. & \multicolumn{1}{|c|}{ Particulars } & MPS & Rank \\
\hline 1. & Input Constraints & 69.25 & I \\
\hline 2. & Technical Constraint & 61.43 & II \\
\hline 3. & Socio-cultural constraints & 60.82 & III \\
\hline 4 & General Constraints & 56.24 & IV \\
\hline
\end{tabular}


The data depicts in the table 4 that majority of respondents indentified unavailability of new high yielding varieties of vegetable seeds (81.26 per cent) was major problem in adoption of kitchen gardening followed by lack of irrigation facility (75.50 per cent), unavailability of land for kitchen gardening near residential zone (73.14 per cent), less available of organic manure (64.81 per cent) and unavailability of eco friendly insecticides (51.55 per cent) were the input constraints in adoption of kitchen gardening. Similar result was found by Kanbid and Sharma (1994) and Sethy et al., (2010) unavailability of new high yielding varieties of vegetable seeds was the first important constraint realized.

The data in table 4 revealed the views of farmers about extent of awareness of technical knowhow of improved methods of kitchen gardening. The major constraint faced by the farmers in this category was lack of knowledge about sowing, improved verities, seed rate and sowing time (82.00 per cent) followed by selection of nutritious vegetables (74.45 per cent), identification of major pests and their management (65.64 per cent), lack of knowledge regarding critical growth for irrigation (54.75 per cent), lack of knowledge about manure and fertilizer recommendation (53.76 per cent), seed multiplication (52.12 per cent) and seed treatment (47.35 per cent) which ranked 2, 3, 4, 5, 6 and 7 were minor technological constraints as perceived by the farmers respectively. It was supported by Sisodia and Rathore (2004) and Kumar et al., (2011) in regards to inadequate knowledge about the selection of nutritious fruits and vegetables (75.35 per cent) ranked 2 nd as farmers mostly relied upon cucurbitaceous vegetables.

The data presented in table 4 indicated that fear of theft of the farm produce (72.31 percent) realized as most important sociocultural constraint followed by farmers tendency of non using practice until other farmers in the social system to use the same (64.55 per cent). So these two causes ranked 1 st and 2nd respectively. Continuous use of traditional package of practice (60.76 per cent) and non use of improved technology was another factor that set back kitchen gardening and it ranked 3rd. Two common trends were observed in the study areas first one was migration of rural youth to urban areas in search of work (55.26 per cent) and another one was decreasing involvement or interest of women of middle class family towards cultivation (51.23 per cent). These two factors were perceived as constraints though with least magnitude by the respondents and ranked at 4th and 5th position respectively.

The data presented in the table 4 indicated that high monkey menace (71.86 per cent) in the kitchen garden was ranked 1st position by the farmers in general category as it was difficult to take any measures against the destruction. Improper protection measures against grazing of cattle and goat (60.15 per cent) ranked 2nd in this category which also cause a major destruction of the garden. The other important constraint considered by the farmers was kitchen gardening gets less priority than other farm activities (52.19 per cent) which ranked on 3rd position. Frequent inundation of water in kitchen garden (40.78 per cent) during rainy season was perceived as minor constraint by the respondent and depicted on last position of the rank. The similar result was found by Sharma and Kalla (2011).

Category-wise constraints as perceived: In order to find out the relationship between the ranks accorded by groups of respondents to different category of constraints, rank order correlation was calculated (Table 5). It is clear that the major category of constraint i.e. input constraint (69.25 per cent) was the top ranked as perceived by the farmers having 
kitchen garden. Other major category of constraints as perceived by the farmers in kitchen gardening like technical constraints (61.43 per cent) and socio-cultural constraints (60.82 per cent) were accorded II and III ranks in rank order by the respondents. Whereas, the general constraints, ranked IV (56.25) were perceived least important. These results were in conformity with the results obtained by kumar et al., (2011).

\section{References}

Javat Hansraj, Patel, M.M., Kumar, K.S. and Saxena Arvind. 2011. Impact of front line demonstrations on scientific temperament of wheat growers. Rajasthan J. Extension Education, (17-18): 115-117.

Kanbid, B.R. and Sharma, D.D. 1994. Adoption constraints of scientific horticultural technology. Indian J. Extension Education, XXX (1 and2):119-122.

Kumar, P., Peshin, R., Nain, M.S. and Manhas, J.S. 2011. Constraints in pulses cultivation as perceived by the farmers. Rajasthan J. Extension Education, (1718): 33-36.
Meena, S.R. and Sisodiya, S.S. 2004. Constraints as perceived by the respondents in adoption of recommended guava production technology. Rajasthan J. Extension Education, (12-13): 146-153.

Sethy, S., Sarkar, S. and Kumar, M. 2010. Constraints in adoption of improved techniques of kitchen gardening. Indian Res. J. Extension Education, X (2): 89-92.

Sharma, P. and Kalla, P.N. 2011. Constraints perceived by the union officials of Urmul Bikaner. Rajasthan J. Extension Education, (17-18): 44-47.

Singh Anita, Sharma, S.K. and Henry Chitra. 2010. Impact of women SHGs in changing socio economic status of rural families in Bikaner District of Rajasthan. Rajasthan J. Extension Education, (1718): 112-114.

Sisodiya, S.S. and Rathore, O.S. 2004. Constraints in adoption of improved groundnut cultivation practices faced by the farmers in Udaipur district of Rajasthan. Rajasthan J. Extension Education, (12-13): 91-94.

Warde, P.N., Bhope, R.S. and Chaudhary, D.P. 1991. Adoption of dry land horticulture technology. Maharashtra J. Extension Education, X(2):108.

\section{How to cite this article:}

Deepa Indoria, C.M. Balai, Bharti and Solanki, R.L. 2017. Adoption Constraints of Improved Techniques for Kitchen Gardening in Chittorgarh District of Rajasthan, India. Int.J.Curr.Microbiol.App.Sci. 6(5): 2351-2356. doi: https://doi.org/10.20546/ijcmas.2017.605.263 